\title{
Application Analytic Hierarchical Process (AHP) in Setting up Local Community Urban Environmental Quality of Life Index in a Developed Metropolitan Area in Ho Chi Minh City, Vietnam
}

\author{
Thu Thi Minh Nguyen ${ }^{*}$, Hang Thi Thu Nguyen1, \\ Tuan Doan ${ }^{1}$, Doan Quang Tri ${ }^{2}$ \\ ${ }^{1}$ Department of Environmental Sciences, SaiGon University, Ho Chi Minh City, Vietnam \\ ${ }^{2}$ Vietnam Journal of Hydrometeorology, Viet Nam Meteorological and Hydrological Administration, Hanoi, Vietnam \\ Email: ${ }^{*}$ tmthu@sgu.edu.vn
}

How to cite this paper: Nguyen, T. T. M., Nguyen, H. T. T., Doan, T., \& Tri, D. Q. (2021). Application Analytic Hierarchical Process (AHP) in Setting up Local Community Urban Environmental Quality of Life Index in a Developed Metropolitan Area in Ho Chi Minh City, Vietnam. Current Urban Studies, 9, 376-391.

https://doi.org/10.4236/cus.2021.93023

Received: July 11, 2021

Accepted: August 1, 2021

Published: August 4, 2021

Copyright $\odot 2021$ by author(s) and Scientific Research Publishing Inc. This work is licensed under the Creative Commons Attribution International License (CC BY 4.0).

http://creativecommons.org/licenses/by/4.0/ (c) (i) Open Access

\begin{abstract}
Evaluation of the quality of the living environment, especially urban areas, is a broad category. It includes both the quality of the surrounding natural environment, the spatial perception, and the emotional linkage between humans and the surrounding environment. This study was conducted to determine the main environmental quality factors selected by people in the urban area of District 1 of Ho Chi Minh City. By surveying local residents and the environmental officers at the ward level People's Committees, the research applied the Analytic Hierarchical Process method to calculate the important level of the introduced environmental quality indicators. The results of the two groups of people were quite similar, and the highest scored indicator groups are the surrounding environmental quality including soil, water, and air. Landscape, odor, and solid waste factors were not appreciated by the residents as they are not the biggest issues at the site. The results of this study, therefore, are expected to be an important reference for policymakers and environmental managers in formulating plans and strategies for protection and improvement of the living environmental quality in the area.
\end{abstract}

\section{Keywords}

Analytic Hierarchical Process, Environmental Quality of Life Index, Urban Quality of Life, Ho Chi Minh City, Vietnam 


\section{Introduction}

Studies on quantifying a person's satisfaction with life have been carried out for many years. However, due to its multidimensionality and ambiguity, the meaning of quality of life may differ from person to person in various frameworks (Estoque et al., 2019). By definition, WHO states the quality of life of an individual as "a perception of their position in life in the context of the culture and value systems in which they live and concerning their goals, expectations, standards, and concerns" (WHO, 2021). Developing a quality of life index has become vital for sustainable development and a center of social policy (Wang et al., 2021). In general, the index should integrate objective and subjective indicators, an extensive range of life domains, and also individual values (Felce \& Perry, 1995; Murgas \& Klobucnik, 2018). EU (2015) mentioned that the index should include employment, health status, social relationships, leisure time, education level, environmental quality, security, and governance. In a context of a community, it could be measured by health, environmental issues, economic dynamics, or children's well-being (Greenwood, 2001). In special contexts such as dense urban areas, it becomes the urban quality of life index. Murgas and Klobucnik (2018) stated that urban quality of life refers to the well-being and quality of the place where the individual lives, as opposed to the quality of life which is the quality of life of the individual, regardless of whether in a city or village. Alibegović and De Villa (2008) confirmed that the indicators specifying environmental, economic, governance, and management perspectives are a useful tool for the city's development towards sustainability. Urban quality indicators have been widely studied for many years and applied in developed urban areas such as the USA (Berenyi, 1972; Hancock, 2002), European countries (Davis \& FineDavis, 1991; Alibegović \& De Villa, 2008; Garau \& Pavan, 2018; Rajaonson \& Tanguay, 2019), some of the Asian countries such as Malaysia (Arif et al., 2015), Hongkong (Low et al., 2018); Pakistan (Ghalib et al., 2017) or China (Tong et al., 2006).

Although many studies have been carried out, there are differences in the selection of environmental quality indicators for urban areas. Regardless of the study location, this difference comes from the dissimilar methodologies of selecting indicators. In general, there are three fundamental methods for establishing environmental quality indicators (Westfall \& de Villa, 2001). They include policy and regulation-based approach which is the indicators built based on experts or to examine a policy, such as urban indicators set for Asian cities (Westfall \& de Villa, 2001); thematic approach which is focusing on defined problems such as environmental or social prosperity, such as Environmental indicators (OECD, 2008); and systems approach such as PSR (Pressure-Status-Response) or DPSIR (Drivers-Pressure-State-Impact-Response) frameworks (OECD, 2008; Westfall \& de Villa, 2001). By referencing many peer-review articles about different types of sustainable indicators, Huang et al. (2015) found that many of them were built based on PSR framework, DPSIR model, or the energy and material flow structure. 
Therefore, Huang et al. (2015) proposed to use the PSR framework to reduce arbitrariness in the selection process. Also, because of its simplicity, measurability, and accessibility, Shathy and Reza (2016) suggested applying DPSIR in setting a new Environmental Integrity Index including three aspects: environmental hazards and vulnerabilities; urban climate; and urban landscape dispersion. Other authors, including Fehr et al. (2004), however, proposed a set of indicators built by a bottom-up model with the participation of social organizations and the local community. In the study, Fehr et al. (2004) argued that this model has the advantage of being efficient and cost-effective. Van der Maesen (2013) suggested the construction of social quality indicators should start from theoretical assumptions which are based on the complexity of society. Cusso et al. (2016) stated that the index development based on a community is able to link practice and theory with policy objectives to develop better public policy. It is useless unless they are understood, recommended, developed, and applied in partnership with residents, multi-levels of government, planners, supporting groups, academics, community organizations, and charitable groups. Likewise, the selected indicators are also essential. Because of differences in selecting methodology the indicators built are also various. Also, the selection of individual indicators to measure specific aspects of sustainability is often subjective and depends on which issues are important (Huang et al., 2015). In the context of an urban quality index, one of the attributes is environmental quality. This feature has been built to a different set of indicators, presented in Table 1.

In the assessment of the performance of the 18 Asian cities, Westfall and de Villa (2001) applied the policy-based approach for indicators' selection because of its comprehensiveness, direct policy relevance, and fully developed consultation. However, these indicators may not reflect the actual requirements of the residents as they are completely chosen by experts and senior managers. Another method is choosing the indicators based on the community's preference. Choosing the right indicators will helps local communities focus on the prominent and prioritized issues. However, this method has disadvantages, including the differences in the individual conception of quality of life, and too focusing on a prominent community issue such as increasing employment rates or improving the environment that ignoring or downplaying other issues (Greenwood, 2001). Another issue raised from setting indicators is whether they are useful for analyzing trends and contradictions in social circumstances worldwide (Van der Maesen, 2013; Rajaonson \& Tanguay, 2019; MacLean \& Salama, 2019).

In this study, therefore, in line with building an index of surrounding environmental quality focusing on outstanding issues raised by residents, we applied an integrated model of a bottom-up framework (Fehr et al., 2004; Cusso et al., 2016) and a policy-based approach (Westfall \& de Villa, 2001). In this way, we referred to and selected developed indicators from recent studies and in urbanized areas with similar social patterns to Vietnam (Satos \& Martins, 2007; Westfall \& de Villa, 2001; Fehr et al., 2004). We then conducted a survey on local managers 
Table 1. Summary of selected indicators for urban environmental sub-set of different authors.

\begin{tabular}{|c|c|}
\hline Name of the index & Indicators \\
\hline $\begin{array}{l}\text { Sustainable urban environmental } \\
\text { quality (Hancock, 2002) }\end{array}$ & $\begin{array}{l}\text { Environmental cleanliness, ecological sustainability, urban livability, community livability, social justice, } \\
\text { and economic adequacy }\end{array}$ \\
\hline $\begin{array}{l}\text { Environmental quality indicators } \\
\text { (Tong et al., 2006) }\end{array}$ & Ambient air quality and grassland degradation \\
\hline $\begin{array}{l}\text { Environmental quality } \\
\text { (Pazhuhan et al., 2020) }\end{array}$ & $\begin{array}{l}\text { Satisfaction level of pedestrian, night lightening, educational facilities, daily transportation to work and } \\
\text { shopping, green and entertainment areas; degree of being annoyed by noises in open environments. }\end{array}$ \\
\hline $\begin{array}{l}\text { Environmental Integrity Index } \\
\text { (Shathy \& Reza, 2016) }\end{array}$ & Environmental hazards and vulnerabilities; urban climate; and urban landscape dispersion \\
\hline $\begin{array}{l}\text { Urban environmental quality criteria } \\
\text { (Baklazhenko et al., 2019) }\end{array}$ & $\begin{array}{l}\text { Ability to create change and transformation; Urban spaces are accessibilities; Ability to choose urban } \\
\text { features; Roads for everyone; Ability to physically sense in urban spaces; Individual acceptance to urban } \\
\text { space; Prioritizing park spaces; Selection of suitable building materials; Community connection }\end{array}$ \\
\hline $\begin{array}{l}\text { Environment characteristics } \\
\text { (Garau \& Pavan, 2018) }\end{array}$ & Quality of urban landscape, Green maintenance \\
\hline $\begin{array}{l}\text { Environmental conditions } \\
\text { (Satos \& Martins, 2007) }\end{array}$ & $\begin{array}{l}\text { Green spaces: Public green spaces per capita, Length of leafy streets; Climate: Days of rainfall, Average of } \\
\text { hours of sunlight per day; Noise: Noise disturbance; Air quality: Days with a Good or Very Good Air } \\
\text { Quality Index; Bathing water quality: Records of Good bathing water quality; Basic infrastructure: } \\
\text { Treated wastewater; Recoverable municipal solid waste }\end{array}$ \\
\hline $\begin{array}{l}\text { The City Noise-Air index } \\
\text { (Silva \& Mendes, 2012) }\end{array}$ & $\begin{array}{l}\text { City Noise (dBA) and City Air (CO: carbon monoxide, } \mathrm{NO}_{2} \text { : nitrogen dioxide, } \mathrm{PM}_{10} \text { : particulate matter } \\
\text { less than } 10 \mu \mathrm{m}, \mathrm{C}_{6} \mathrm{H}_{6} \text { : benzene, and } \mathrm{O}_{3} \text { : ozone) }\end{array}$ \\
\hline $\begin{array}{l}\text { Environmental quality indicators } \\
\text { (Sarmento et al., 2000) }\end{array}$ & $\begin{array}{l}\text { Accessibility to infrastructure services: supply of clean water, electricity, telecommunications, garbage } \\
\text { collection, drainage, public transport, sidewalks; Surrounding environment: trees, street cleaning services, } \\
\text { air quality, park areas, movable street areas, indicators of social structure (number of schools, clinics, } \\
\text { police stations, churches/community centers, etc.); Public service: health care index, reading and library } \\
\text { services index, entertainment indexes such as cinemas and nightlife, security indicators and safety, } \\
\text { learning indicators. }\end{array}$ \\
\hline $\begin{array}{l}\text { Environmental parameters } \\
\text { (Fehr et al., 2004) }\end{array}$ & $\begin{array}{l}\text { Demographic density and evolution; public transportation; solid waste handling; liquid effluent handling; } \\
\text { air monitoring; freshwater supply; public education; public health care; cultural manifestations; energy } \\
\text { supply; park maintenance; land use and resource preservation }\end{array}$ \\
\hline $\begin{array}{l}\text { Environmental indicators } \\
(\mathrm{OECD}, 2008)\end{array}$ & $\begin{array}{l}\text { Climate change: } \mathrm{CO}_{2} \text { and greenhouse gas emission intensities; Ozone layer: ozone-depleting substances; } \\
\text { Air quality: } \mathrm{SO}_{\mathrm{x}} \text { and } \mathrm{NO}_{\mathrm{x}} \text { emission intensities; Waste generation: municipal waste generation intensities; } \\
\text { Freshwater quality: wastewater treatment connection rates; Freshwater resources: intensity of use of water } \\
\text { resources; Forest resources: intensity of use of forest resources; Fish resources: intensity of use of fish } \\
\text { resources; Energy resources: intensity of energy use; Biodiversity: threatened species }\end{array}$ \\
\hline
\end{tabular}

and people in the study area to adjust the set of criteria according to the people's most concern.

\section{Materials and Methods}

\subsection{Methodology}

The study is aimed to build a system of indicators for a local community, which focuses on the most concerned issues on environmental quality. Therefore, this study applies the methodology combined the policy-based and bottom-up approaches. We surveyed 24 state officers responsible for environmental management in the area. These people are not law-policy experts or environmental researchers, they are working staff at the lowest level of the local authority, that is 
the ward or commune level. These officers were chosen as the first step of selection indicators because they are working directly with the residents, and therefore understanding the raising problems at the site. A similar survey was also conducted for local people but at a more basic level. A total of 233 people living and working in 10 wards of the District 1 were surveyed. Survey results were used to compare with the results of state employees for comparison and calibration.

\subsection{Selection of Environmental Quality Indicators}

The selection of appropriate criteria plays an important role in determining the raising concerns and is the basis for a more accurate assessment of environmental quality. In some studies in developed urban areas, the environmental quality indicators were focused on developing the linkage between humans and nature (Sarmento et al., 2000; Hankok, 2002; Baklazhenko et al., 2019; Pazhuhan et al., 2020). Also, the application of these indicators needs to consider the cultural and lifestyle conditions of the study area. The indicators are therefore should be based on the complexity of society, and selecting key issues (Van der Maesen, 2013; Rajaonson \& Tanguay, 2019; MacLean \& Salama, 2019).

Consequently, we had considered the nature of the study area before choosing the indicators. In the study, we research the environmental quality in District 1 , Ho Chi Minh City, Vietnam. This is an area with a long history of development, dating back to 1859 . Over the years, the area has developed into one of the most developed urban areas in Ho Chi Minh City. It is a center of many administrative offices and commercial buildings. Due to a long time of development, along with the high density of population, the infrastructure system gradually becomes overloaded and causes negative impacts on the surrounding environment. We noticed some problems such as land subsidence due to long-term groundwater exploitation, limited drainage capacity because of the old and overloaded drainage system, lack of green spaces due to the high density of construction and residence area. In particular, noise pollution is also one of the problems affecting the quality of life, specifically noise caused by transports and street vendors. Another issue is odor. Ho Chi Minh City, a Southeast Asia urban area, has been affected by the Asian street culture such as street food, outdoor gatherings, and also littering habits. Therefore, we added the odor factor as an indicator of environmental quality, particularly the smell from decomposing uncollected garbage, the sewer, or the smoke from the street's food carts.

Consequently, after consulting different sets of criteria (Table 1) and based on our understanding of the general situation of the region, we proceeded to develop an initial set of criteria including 07 components: Soil/Land; Water; Atmosphere, Landscape, Noise; Odor; and Solid Waste. Each environmental component consists of 3 to 5 indicators, presented in Table 2.

\subsection{Method for Determining Weighting Values of the Indicators}

Determining the prioritizing level, or weight, of each concurrent indicator is an 
Table 2. Suggested Environmental Quality Indicators for the urban environment in the study area.

\begin{tabular}{|c|c|}
\hline Sub-index & Indicators \\
\hline \multirow{3}{*}{$\begin{array}{l}\text { 1. Soil/Land } \\
\text { (Shathy \& Reza, 2016; Pazhuhan et al., 2020) }\end{array}$} & 1.Land subsidence condition \\
\hline & 2. Percentage of land for green area \\
\hline & 3. Soil pollution \\
\hline \multirow{5}{*}{$\begin{array}{l}\text { 2. Water quality } \\
\text { (Fehr et al., 2004; OECD, 2008) }\end{array}$} & 1. Quality of water supply \\
\hline & 2. Quality of natural water \\
\hline & 3. Surface and groundwater pollution \\
\hline & 4. Drainage capability of the area \\
\hline & 5. Groundwater's exploitation \\
\hline \multirow{4}{*}{$\begin{array}{l}\text { 3. Air quality } \\
\text { (Silva \& Mendes, 2012) }\end{array}$} & 1. Particulate matters \\
\hline & 2. Transport air pollution \\
\hline & 3. Pollution from business establishments \\
\hline & $\begin{array}{l}\text { 4. Pollution from burning coal, garbage, or other } \\
\text { items outdoors }\end{array}$ \\
\hline \multirow{3}{*}{$\begin{array}{l}\text { 4. Landscape } \\
\text { (Pazhuhan et al., 2020, Garau \& Pavan, 2018) }\end{array}$} & 1. Surrounding green and entertainment areas \\
\hline & $\begin{array}{l}\text { 2. Openness level of the surrounding } \\
\text { environment }\end{array}$ \\
\hline & 3. Surrounding Ecosystem \\
\hline \multirow{3}{*}{$\begin{array}{l}\text { 5. Noise } \\
\text { (Silva \& Mendes, 2012; Pazhuhan et al., 2020) }\end{array}$} & 1. Noise from vehicles \\
\hline & 2. Noise from business activities \\
\hline & 3. Noise from construction activities \\
\hline \multirow{4}{*}{$\begin{array}{l}\text { 6. Odor } \\
\text { (from practical experiences of the research team } \\
\text { in the studied area) }\end{array}$} & 1. Odor from untreated garbage \\
\hline & 2. Odor from sewers \\
\hline & $\begin{array}{l}\text { 3. Odor from outdoor business activities (such } \\
\text { as: street vendor) }\end{array}$ \\
\hline & $\begin{array}{l}\text { 4. Odor from solid waste transfer stations and } \\
\text { landfills }\end{array}$ \\
\hline \multirow{4}{*}{$\begin{array}{l}\text { 7. Solid waste } \\
\text { (Sarmento et al., 2000; Fehr et al., 2004; OECD, } \\
\text { 2008) }\end{array}$} & 1. Volume of waste generated $(\mathrm{kg} /$ day/person) \\
\hline & 2. Waste composition \\
\hline & 3. Percentage of waste collected/recycled \\
\hline & $\begin{array}{l}\text { 4. Solid waste pollution (street garbage, litter on } \\
\text { sewers) }\end{array}$ \\
\hline
\end{tabular}

important issue when considering the overall environmental quality. In some studies, sets of new and relevant indicators were introduced without mentioning specific weights or calculation methods (Sarmento et al., 2000; Satos \& Martins, 2007; Baklazhenko et al., 2019). Ambreen et al. (2018) directly converted the measured values of each indicator into non-unit (normalized) values that range from 0 to 1 , where values close to 1 indicate better sustainability and values close to 0 indicate weak sustainability. In some other studies, the overall results of all the indicators were calculated as the mean value of single indicators (Westfall \& 
de Villa, 2001; Shathy \& Reza, 2016; Suvorov et al., 2018). Huang et al. (2015) recommended applying statistical methods such as Regression Analysis, Principal Component Analysis, Factor Analysis, Analytic Hierarchical Process, or Linkage Analysis for their better accuracy. In this study, Analytic Hierarchical Process (AHP) method was applied to set the weighting value to each proposed indicator. The main advantage of this method is that high weighted values are assigned to the indicators considered to be more important. Steps for conducting this method include setting up scoring values, setting up the evaluating matrix, and checking the consistency of the results (Kousalya et al., 2012).

First, a scale of pairwise comparison was set and ranged from 0 to 9 . Then a questionnaire was built and surveyed to two groups of people: the state officers and the residents. Indicators are divided into two levels, level 1: the seven component types of indicators including Water; Atmosphere, Landscape, Noise; Odor; and Solid Waste; and level 2: the sub-indicators in each component group (Table 2 ). The matrix of the evaluation was then set to assess the results. The consistency of the matrix was also checked by the Consistency Ratio (CR). The CR value should be less than or equal to 0.1 . CR is the ratio of the Consistency Index (CI) and the Random Index (RI):

$$
C R=C I / R I
$$

where

$$
C I=\left(\lambda_{\max }-n\right) /(n-1)
$$

$\lambda_{\max }$ (specific value of comparison matrix) $=$ average value of consistent vector

Consistent vector $=$ weighted sum vector/weight vector

Weighted sum vector $=$ matrix comparing $\times$ weight vectors

$\mathrm{N}$ is the number of elements in the comparison matrix, in the study $\mathrm{n}=7$.

$\mathrm{RI}$ is chosen $1.350(\mathrm{n}=7)$ (Kousalya et al., 2012).

\subsection{Questionnaire's Development}

\subsubsection{Questionnaire Design Principle}

The study aims to survey people using a questionnaire. Unlike the interview, this study relies on the respondents to fill in the information themselves, so the survey form is designed with closed-ended questions. The design principle of the questionnaire is simple to understand, not confusing, and save time answering. The short questions together with the scoreboard are therefore designed to be simple and concise in order to obtain the needed information without causing difficulties to the respondents (Sreejesh et al., 2014). The content of the survey consists of 2 main parts: part 1 is general information about the respondent, and part 2 is the evaluation part for scoring on the quality of the environment.

\subsubsection{Questionnaire's Reliability}

The survey applies Saaty's 9-level scale (Kousalya et al., 2012). Before making on-site surveying, the questionnaire was tested and checked by the research team. 
The questions were uniquely built and not duplicated. In the questionnaire, pairwise comparison is taken place at the same level of the indicator's group. For the group of local people, we found that the comparison between factors should be simple and easy to understand so that people are not confused and mistaken. However, for the group of state officers, the measurement is extended to 9 levels because this group of people has more specialized expertise in the environmental management field (Table 3).

\subsubsection{Questionnaire's Validity}

The survey results were expectedly subjective based on life experiences and personal feelings of the respondents. Therefore, to evaluate the validity of the survey, we divided the respondents into 2 groups, in which the main target group is 233 people living in the study area, and the evidence is a group of 24 governmental officers at ward and commune level. The survey results of these two groups will be compared for similarity. If the results of the two groups are similar, it can be assumed that the results are authentic and reflect reality in the surveyed area.

\section{Results and Discussion}

\subsection{Descriptive Analysis of the Respondents}

\subsubsection{Local Residents}

A total of 233 respondents were surveyed across 10 wards in the region, including: Tan Dinh, Ben Nghe, Ben Thanh, Cau Kho, Co Giang, Cau Ong Lanh (COLanh), Da Kao, Nguyen Cu Trinh (NgCuTrinh), Nguyen Thai Binh (NgThBinh), and Pham Ngu Lao (PhNgLao) (Figure 1(a)). The male and female ratios are $46.35 \%$ and 53.65\%, respectively. Most of the respondents are the office workers (41.6\%), and more than $70 \%$ of the asked people are College/University graduate. The average age of the respondents is 38.6 , the average duration of living is more

Table 3. Scale for pairwise comparison between Factor 1 and Factor 2.

\begin{tabular}{|c|c|c|}
\hline Score & Important level & Explanation \\
\hline \multicolumn{3}{|c|}{ For state officers' survey } \\
\hline 1 & Equal & Two equally important factors \\
\hline 3 & Relatively higher & Factor 1 is relatively more important than the other \\
\hline 5 & Higher & Factor 1 is more important than the other \\
\hline 7 & Much higher & Factor 1 is more important than the other \\
\hline 9 & Much more higher & Factor 1 is more important than the other \\
\hline $2,4,6,8$ & Intermediate values & Values in between the two rating levels \\
\hline \multicolumn{3}{|c|}{ For residents' survey } \\
\hline 1 & Equal & Two equally important factors \\
\hline 9 & More important & Factor 1 is more important than the other \\
\hline $1 / 9$ & Less important & Factor 1 is less important than the other \\
\hline
\end{tabular}


than 19 years, and typical income per month is nearly 435 USD (10 million Vietnam Dong-VND) (Table 4).

\subsubsection{Local Authorities}

Twenty four local authorities have provided their information about education, work specialization, research and teaching situation and state management activities (Figure 1(b)). Of the 24 surveyed, those with university/college degrees accounted for more than $90 \%$, and two have master's degrees. Two people $(8.3 \%)$ participate in teaching activities at universities/colleges. In terms of work specialization, all are working in the field of urban related and environmental management.

\subsection{Weight Results of the Suggested Indicators}

\subsubsection{Weight Results of the Component Indicators}

The results of the preference of 24 local authorities and 233 people are shown in Table 5 .

Table 4. Descriptive analysis of 223 respondents by age, income, working and living period.

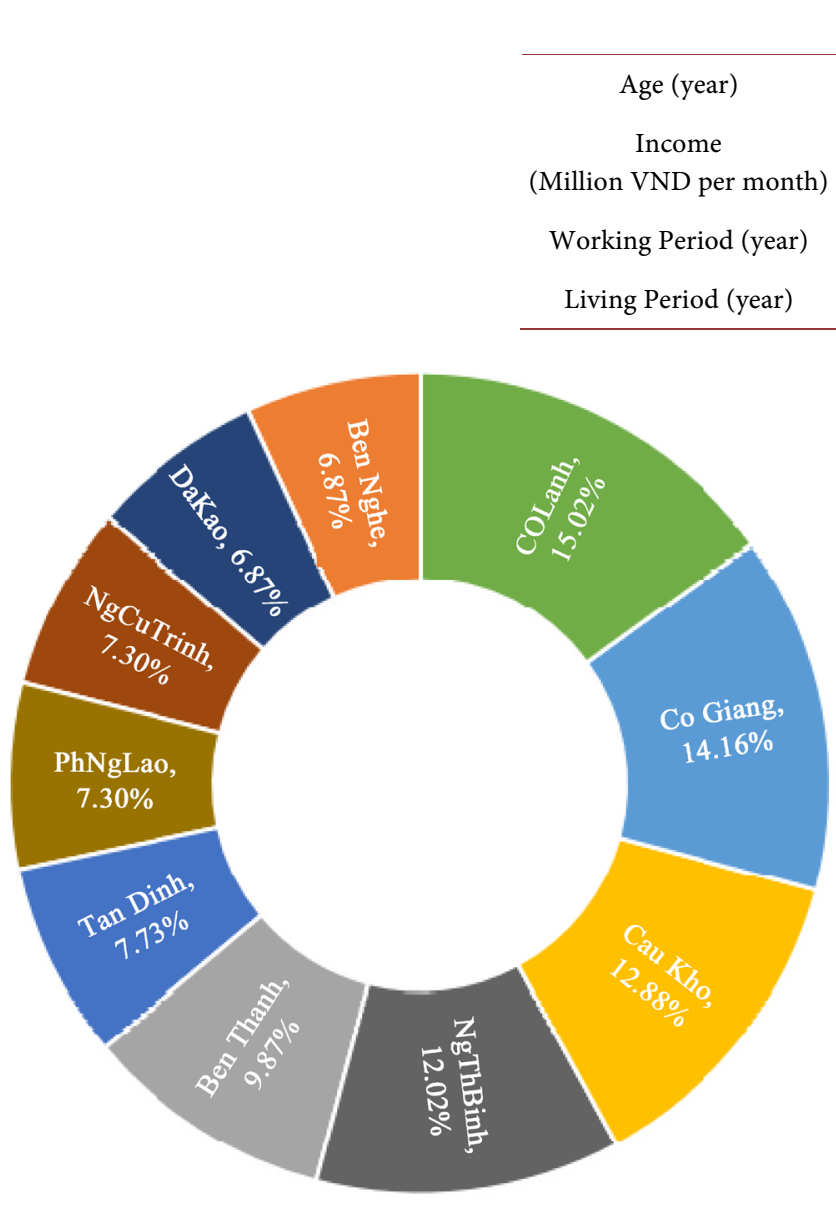

(a)

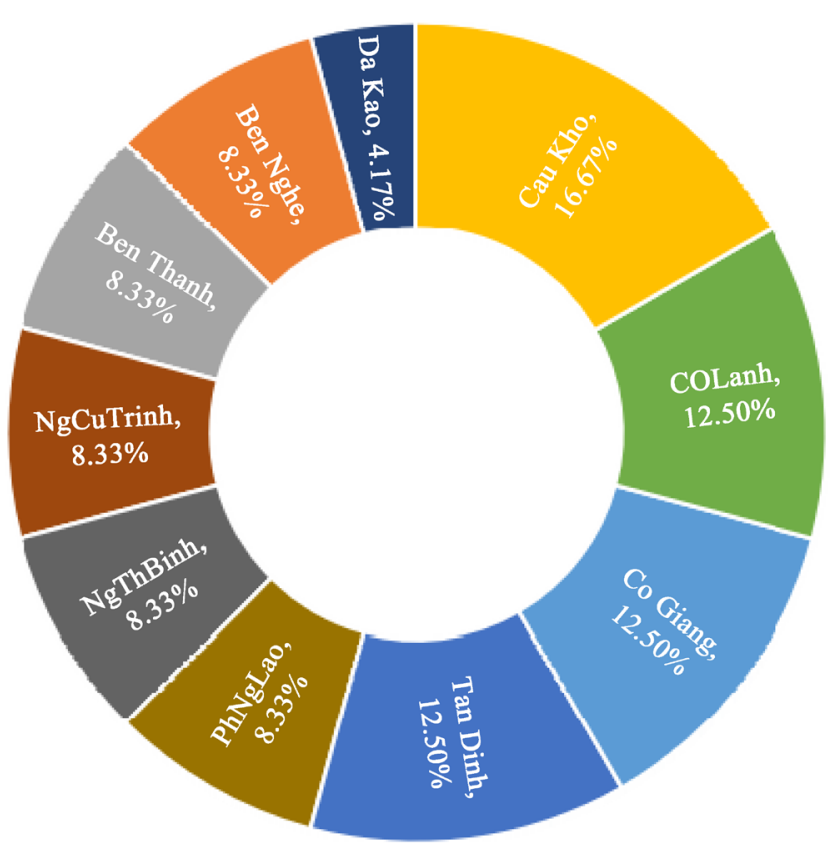

(b)

Figure 1. Frequency distribution by places of (a) 233 surveyed residents and (b) 24 local authorities. 


\subsubsection{Weight Results of the Sub Indicators}

The results of the importance level of the sub-indicators of 24 local authorities are shown in Table 6.

Table 5. Weights results of seven component indicators.

\begin{tabular}{lcc}
\hline & Local authorities & Residents \\
\hline Number surveyed: & 24 & 233 \\
CR coefficient: & 0.104 & 0.105 \\
\hline & Weight of the indicators: & \\
\hline 1. Soil/Land & 0.191 & 0.348 \\
2. Water quality & 0.279 & 0.208 \\
3. Air quality & 0.181 & 0.192 \\
4. Landscape & 0.124 & 0.105 \\
5. Noise & 0.130 & 0.062 \\
6. Odor & 0.059 & 0.046 \\
7. Solid waste & 0.036 & 0.039 \\
\hline
\end{tabular}

Table 6. Weights results of seven component indicators (number surveyed: 24).

\begin{tabular}{|c|c|c|c|}
\hline Component & Label & Sub-index & Weight \\
\hline \multirow{3}{*}{$\begin{array}{l}\text { 1. Soil/Land } \\
(\mathrm{CR}=0.094)\end{array}$} & 1.1 & Land subsidence condition & 0.13 \\
\hline & 1.2 & Percentage of land for green area & 0.58 \\
\hline & 1.3 & Soil pollution & 0.29 \\
\hline \multirow{5}{*}{$\begin{array}{l}\text { 2. Water quality } \\
(\mathrm{CR}=0.105)\end{array}$} & 2.1 & Quality of water supply & 0.07 \\
\hline & 2.2 & Quality of natural water & 0.12 \\
\hline & 2.3 & Surface and groundwater pollution & 0.20 \\
\hline & 2.4 & Drainage capability of the area & 0.28 \\
\hline & 2.5 & Groundwater's exploitation & 0.33 \\
\hline \multirow{4}{*}{$\begin{array}{l}\text { 3. Air quality } \\
(\mathrm{CR}=0.081)\end{array}$} & 3.1 & Particulate matters & 0.63 \\
\hline & 3.2 & Transport air pollution & 0.08 \\
\hline & 3.3 & Pollution from business establishments & 0.13 \\
\hline & 3.4 & Pollution from burning coal, garbage, or other items outdoors & 0.16 \\
\hline \multirow{3}{*}{$\begin{array}{l}\text { 4. Landscape } \\
(\mathrm{CR}=0.038)\end{array}$} & 4.1 & Surrounding green and entertainment areas & 0.15 \\
\hline & 4.2 & Openness level of the surrounding environment & 0.65 \\
\hline & 4.3 & Surrounding Ecosystem & 0.21 \\
\hline \multirow{3}{*}{$\begin{array}{c}\text { 5. Noise } \\
(\mathrm{CR}=0.102)\end{array}$} & 5.1 & Noise from vehicles & 0.16 \\
\hline & 5.2 & Noise from business activities & 0.54 \\
\hline & 5.3 & Noise from construction activities & 0.30 \\
\hline \multirow{4}{*}{$\begin{array}{c}\text { 6. Odor } \\
(\mathrm{CR}=0.054)\end{array}$} & 6.1 & Odor from untreated garbage & 0.12 \\
\hline & 6.2 & Odor from sewers & 0.17 \\
\hline & 6.3 & Odor from outdoor business activities (such as street vendor) & 0.29 \\
\hline & 6.4 & Odor from solid waste transfer stations and landfills & 0.41 \\
\hline \multirow{4}{*}{$\begin{array}{l}\text { 7. Solid waste } \\
(\mathrm{CR}=0.052)\end{array}$} & 7.1 & Volume of waste generated (kg/day/person) & 0.10 \\
\hline & 7.2 & Waste composition & 0.21 \\
\hline & 7.3 & Percentage of waste collected/recycled & 0.35 \\
\hline & 7.4 & Solid waste pollution (street garbage, litters on sewers) & 0.33 \\
\hline
\end{tabular}




\subsection{Discussion}

\subsubsection{Weight Results of the Component Indicators}

The CR coefficient of the two survey groups is about $10 \%$ (Table 5), which shows that the results of the survey respondents' opinions are quite similar and therefore the calculated weights are significant. The results show the similarity in the survey opinions of the two groups of people when ranking the importance of environmental quality factors in the living and working areas.

The environmental elements including soil, water, and air quality were assessed as the most important by both groups, as the total weighting values of these three indicator groups is about $65 \%$ for both survey groups. In the group of the three most important environmental quality factors, the local authorities group assessed that the factor of water quality played the most important role while the group of residents believed that the quality of the soil was the most important factor (Table 5).

The three least important indicator groups surveyed were solid waste, odor and landscape (for local authorities group), and solid waste, odor, and noise (for resident group), about which shows that these factors are not current issues that the community concerned.

\subsubsection{Weight Results of the Sub Indicators}

Assessing more detail the component indicators in each group of environmental quality indicators, the survey results of community workers showed a degree of consensus in evaluating which factors play an important role. This consistency is presented through the $\mathrm{CR}$ value of all sub-indices of seven environmental quality indexes are within the limit of $10 \%$ allowance (Table 6).

The AHP's results in Table 6 show which criteria play the most important role in the indicator groups. For the soil/land quality group, the indicator Percentage of land for green area accounts for 58\%, which shows the urgent requirements for urban green spaces. The local government also realizes that this is an important factor contributing to improving the quality of life of people in urban areas. Similarly, the indicator: The openness of the surrounding environment of the group of landscape indicators, also accounts for the highest rate of $65 \%$ within the group. These two factors help to reaffirm the community's view on the quality of the living environment in urban areas, which is now much valued about the degree of openness and increasing the rate of contact with nature.

For the group of water quality indicators, the highest percentage result is on the Groundwater exploitation indicator, which reflects the current situation of the area being subsided due to a long time of underground water extraction. Other indicators such as water quality, natural water, and groundwater pollution were also assessed to be of equal importance. Particularly, the indicator of supply water quality is not appreciated, shown by the lowest percentage within the group. This may be the result of supply water quality improvement, and therefore no longer the main concern of local authorities. 
For the group of air quality criteria, the importance level of fine dust (Particulate matters) accounts for $63 \%$, while the indicators of traffic pollution are very low. This shows that respondents are very interested in the problem of fine dust pollution but did not think that the problem of air pollution caused by traffic is a concern in District 1. This is similar to the assessment of the surveyors in the group of noise indicators, in which the assessment of noise caused by traffic is not too high (16\%). These results may be understood that the problems of smoke and noise pollution due to traffic are not too serious in the study area.

For the group of odor indicators, the local authorities recognized that the smell of waste at transfer stations and treatment areas as the most serious problem, and they also identified that littering indiscriminately and the rate of uncollected/reused garbage are the most concerned issues.

\subsubsection{Suggestion of Refined Overall Urban Environmental Quality Index \\ Suggestion of Urban Environmental Quality Index calculation}

From the gained results, we propose a set of indicators of urban environmental quality of life (UEQL) in the study area, including 07 groups of indicators and their coefficients as follow:

$$
\begin{gathered}
\mathrm{UEQL}=26.95 *(\text { Soil } / \text { Land })+24.35 *(\text { Water quality })+18.65 *(\text { Air quality })+ \\
11.45 *(\text { Landscape })+9.60 *(\text { Noise })+5.25 *(\text { Odor })+3.75 *(\text { Solid waste }) .
\end{gathered}
$$

Where the coefficients of indicator groups are the average percentage of the weights presented in Table 5 .

The high coefficient values for the group of natural environment including soil, water, and air quality show the similarity in the assessment of the research team and the surveyed people with respect to the area's quality of the natural environment. The area's environmental quality is currently impacted by population growth, outdated infrastructure, dense construction of residential and commercial areas, and lack of open urban spaces. The coefficient of the Landscape group indicates the increasing concern of residents about the lack of space to interact with nature. Calculation of each component group is therefore recommended as follow (Table 6).

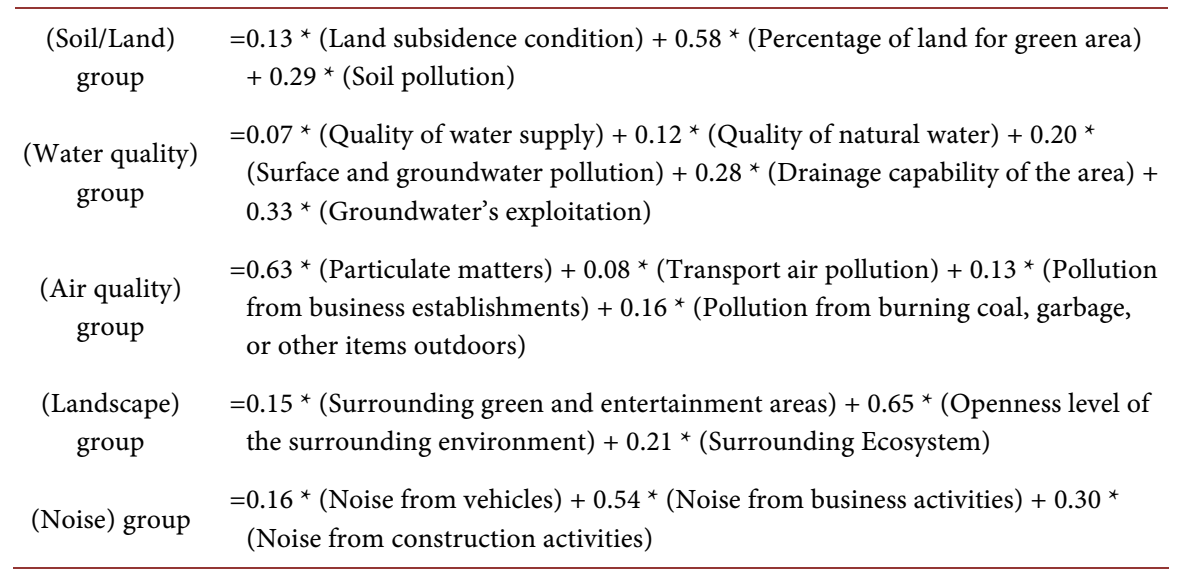


$=0.12 *($ Odor from untreated garbage $)+0.17 *($ Odor from sewers $)+0.29 *$

(Odor) group (Odor from outdoor business activities) $+0.41 *$ (Odor from solid waste transfer stations and landfills)

(Solid waste $)=0.1 *($ Volume of waste generated $)+0.21 *($ Waste composition $)+0.35 *$

group (Percentage of waste collected/recycled) $+0.33 *$ (Solid waste pollution)

We also propose a range of UEQL values between 0 and 1000, which are divided into the following quality categories:

- UEQL from 0 to 400 points: Bad, need much improvement.

- UEQL from 401 to 600 points: Average, need improvement.

- UEQL from 601 to 800 points: Quite Good, consider better improvement.

- UEQL from 801 to 1000 points: Good, need a protection and maintenance plan.

\section{Suggestion of indicator's calculation}

Each component indicator's value is recommended from 0 to 10 with specific measurement. For example, calculating suggestion for every indicator in the Land/ Soil sub-index is presented in Table 7. The research team therefore advises further study on completion of every indicator's measurement method and application to the area for validation.

\section{Conclusions}

\subsection{Shortcomings}

We recognize that the study is deficient in terms of the number of people surveyed. Although this is a pilot study, the obtained results have shown the consensus of the

Table 7. Indicator's calculation in the Land/Soil sub-index.

\begin{tabular}{|c|c|c|c|c|c|}
\hline Indicators & Method & Reference & Unit & Specific value & Score \\
\hline \multirow{3}{*}{$\begin{array}{l}\text { Land } \\
\text { subsidence } \\
\text { condition }\end{array}$} & \multirow{3}{*}{$\begin{array}{c}\text { Practical } \\
\text { measureme } \\
\text { nt }\end{array}$} & \multirow{3}{*}{$\begin{array}{c}\text { The official } \\
\text { report of land } \\
\text { subsidence in the } \\
\text { area }\end{array}$} & \multirow{3}{*}{$\mathrm{cm}^{*}$ year $^{-1}$} & $0-1$ & $8-10$ \\
\hline & & & & $1-10$ & $5-7$ \\
\hline & & & & $>10$ & $0-4$ \\
\hline \multirow{4}{*}{$\begin{array}{c}\text { Percentage of } \\
\text { land for } \\
\text { green area }\end{array}$} & \multirow{4}{*}{$\begin{array}{l}\text { Estimation } \\
\text { based on } \\
\text { statistical } \\
\text { data }\end{array}$} & \multirow{4}{*}{$\begin{array}{c}\text { National } \\
\text { standard for } \\
\text { public green area }\end{array}$} & \multirow{4}{*}{$\begin{array}{l}\mathrm{m}^{2} \text { per } \\
\text { resident }\end{array}$} & $12-15$ & $8-10$ \\
\hline & & & & $8-12$ & $4-7$ \\
\hline & & & & $4-8$ & $2-3$ \\
\hline & & & & $0-4$ & $0-1$ \\
\hline \multirow{3}{*}{ Soil pollution } & \multirow{3}{*}{$\begin{array}{l}\text { Practical } \\
\text { measureme } \\
\text { nt }\end{array}$} & \multirow{3}{*}{$\begin{array}{c}\text { National } \\
\text { standard for } \\
\text { residential soil } \\
\text { quality, } \\
\text { including heavy } \\
\text { metal, chemicals, } \\
\text { pesticides and } \\
\text { insecticides }\end{array}$} & \multirow{3}{*}{$\begin{array}{c}\text { mg } \\
\text { pollutants } \\
\text { per kg of } \\
\text { refined } \\
\text { soil }\end{array}$} & $\begin{array}{l}\text { All the regulated pollutants } \\
\text { are traced or not found }\end{array}$ & $7-10$ \\
\hline & & & & $\begin{array}{l}\text { Less than } 3 \text { pollutants are } \\
\text { found at a higher level than } \\
\text { the limits }\end{array}$ & $4-6$ \\
\hline & & & & $\begin{array}{c}\text { More than } 3 \text { pollutants are } \\
\text { found at higher level than } \\
\text { the limits }\end{array}$ & $0-3$ \\
\hline
\end{tabular}

(Note: information provided in this table is the research team's proposal). 
respondents on environmental quality issues in the community. However, we admit that the average surveying rate of 23.3 people per ward is still low and needs more people's participation. Another aspect of this research is the essential of expert and policy maker consultation, particularly researchers and top governmental managers. Therefore, in the next studies, we plan to expand the number of surveyed residents, develop more survey target groups, build complete methods of quantifying UEQL set, and apply the set to the area for validation.

\subsection{Conclusions}

The development of a set of indicators for urban living environment quality by consulting local people and officers plays an important role in the field of environmental management. This set of indicators not only reflects the content of environmental quality that people consider to be an important issue but also shows people's desire for their surrounding living environment. Therefore, the proposal of this set of criteria based on public consultation should be implemented for its essential for senior managers, policy-makers, environmental experts (especially environmental monitoring specialists) to reference and identify which environmental problems at the site are emerged and needed to be prioritized for remediation or improvement.

\section{Acknowledgements}

We sincerely acknowledge the support of Saigon University, the People's Committees of the 10 Wards in District 1, Ho Chi Minh City for their assistance in completing this research.

\section{Conflicts of Interest}

The authors declare no conflicts of interest regarding the publication of this paper.

\section{References}

Alibegović, D. J., \& De Villa, Ž. K. (2008). The Role of Urban Indicators in City Management: A Proposal for Croatian Cities. Transition Studies Review, 15, 63-80. https://doi.org/10.1007/s11300-008-0171-6

Ambreen, H., Kumar, S., Kumar, A., Agarwal, M., Jagannath, A., \& Goel, S. (2018). Association Mapping for Important Agronomic Traits in Safflower (Carthamus tinctorius L.) Core Collection Using Microsatellite Markers. Frontiers in Plant Science, 9, 402. https://doi.org/10.3389/fpls.2018.00402

Arif, S., Kittelmann, S., \& McGregor, A. P. (2015). From Shavenbaby to the Naked Valley: Trichome Formation as a Model for Evolutionary Developmental Biology. Evolution \& Development, 17, 120-126. https://doi.org/10.1111/ede.12113

Baklazhenko, V. V., Vovzhenyak, P. Y., \& Pavlovskaya, E. E. (2019). The Major Cities Quality Urban Environment Forming Features. IOP Conference Series: Materials Science and Engineering, 698, Article ID: 033004.

https://doi.org/10.1088/1757-899X/698/3/033004 
Berenyi, J. (1972). Urban-Environmental Indicators in Municipal and Neighborhood Policy Planning and Decision Making. In W. A. Thomas (Ed.), Indicators of Environmental Quality (pp. 23-30). Springer. https://doi.org/10.1007/978-1-4684-1698-5 4

Cusso, M. E., Donald, K. J., \& Khoo, T. K. (2016). The Impact of Physical Activity on NonMotor Symptoms in Parkinson's Disease: A Systematic Review. Frontiers in Medicine, 3, 35. https://doi.org/10.3389/fmed.2016.00035

Davis, E. E., \& Fine-Davis, M. (1991). Social Indicators of Living Conditions in Ireland with European Comparisons. Social Indicators Research, 25, 103-365. https://doi.org/10.1007/BF00286160

Estoque, R. C., Togawa, T., Ooba, M., Gomi, K., Nakamura, S., Hijioka, Y., \& Kameyama, Y. (2019). A Review of Quality of Life (QOL) Assessments and Indicators: Towards a "QOLClimate" Assessment Framework. Ambio, 48, 619-638.

https://doi.org/10.1007/s13280-018-1090-3

European Union (EU) (2015). Quality of Life: Facts and Views (268 p.). Luxembourg.

Fehr, M., Sousa, K. A., Pereira, A. F. N., \& Pelizer, L. C. (2004). Proposal of Indicators to Assess Urban Sustainability in Brazil. Environment, Development and Sustainability, 6, 355-366. https://doi.org/10.1023/B:ENVI.0000029914.82071.6e

Felce, D., \& Perry, J. (1995). Quality of Life: Its Definition and Measurement. Research in Developmental Disabilities, 16, 51-74. https://doi.org/10.1016/0891-4222(94)00028-8

Garau, C., \& Pavan, V. M. (2018). Evaluating Urban Quality: Indicators and Assessment Tools for Smart Sustainable Cities. Sustainability, 10, 575. https://doi.org/10.3390/su10030575

Ghalib, A., Qadir, A., \& Ahmad, S. R. (2017). Evaluation of Developmental Progress in Some Cities of Punjab, Pakistan, Using Urban Sustainability Indicators. Sustainability, 9, 1473. https://doi.org/10.3390/su9081473

Greenwood, D. (2001). Local Indicators of Quality of Life: A Preliminary Look at the Pikes Peak Region. Working Paper \#106, Center for Colorado Policy Studies, University of Colorado.

Hancock, T. (2002). Indicators of Environmental Health in the Urban Setting. Canadian Journal of Public Health, 93, 45-51. https://doi.org/10.1007/BF03405118

Huang, L., Wu, J., \& Yan, L. (2015). Defining and Measuring Urban Sustainability: A Review of Indicators. Landscape Ecology, 30, 1175-1193.

https://doi.org/10.1007/s10980-015-0208-2

Kousalya, P., Reddy, G. M., Supraja, S., \& Prasad, V. S. (2012). Analytical Hierarchy Process Approach-An Application of Engineering Education. Mathematica Aeterna, 2, 861878.

Low, C. T., Stimson, R., Chen, S., Cerin, E., Wong, P. P. Y., \& Lai, P. C. (2018). Personal and Neighbourhood Indicators of Quality of Urban Life: A Case Study of Hong Kong. Social Indicators Research, 136, 751-773. https://doi.org/10.1007/s11205-017-1579-3

MacLean, L., \& Salama, A. M. (2019). Towards a Context Specific and Multidimensional Quality of Urban Life Model. Open House International, 44, 25-33. https://doi.org/10.1108/OHI-01-2019-B0004

Murgas, F., \& Klobucnik, M. (2018). Quality of Life in the City, Quality of Urban Life or Well-Being in the City: Conceptualization and Case Study. Ekológia (Bratislava), 37, 183200. https://doi.org/10.2478/eko-2018-0016

Organisation for Economic Co-Operation and Development (OECD) (2008). OECD Key Environmental Indicators. Paris. 
Pazhuhan, M., Shahraki, S. Z., Kaveerad, N., Cividino, S., Clemente, M., \& Salvati, L. (2020). Factors Underlying Life Quality in Urban Contexts: Evidence from an Industrial City (Arak, Iran). Sustainability, 12, 2274. https://doi.org/10.3390/su12062274

Rajaonson, J., \& Tanguay, G. A. (2019). Urban Sustainability Indicators from a Regional Perspective: Lessons from the Montreal Metropolitan Area. Social Indicators Research, 141, 985-1005. https://doi.org/10.1007/s11205-017-1823-x

Sarmento, R., Zorza, F. M. B., Serafim, A. J., \& Allmenroedr, L. B. (2000). Urban Environmental Quality Indicator. WIT Transactions on Ecology and the Environment, 39, 8. https://www.witpress.com/elibrary/wit-transactions-on-ecology-and-the-environment/ $\underline{39 / 4851}$

Satos, L. D., \& Martins, I. (2007). Monitoring Urban Quality of Life: The Porto Experience. Social Indicators Research, 80, 411-425.

https://doi.org/10.1007/s11205-006-0002-2

Shathy, S. T., \& Reza, M. I. H. (2016). Sustainable Cities: A Proposed Environmental Integrity Index (EII) for Decision Making. Frontiers in Environmental Science, 4, 82. https://doi.org/10.3389/fenvs.2016.00082

Silva, L. T., \& Mendes, J. F. G. (2012). City Noise-Air: An Environmental Quality Index for Cities. Sustainable Cities and Society, 4, 1-11. https://doi.org/10.1016/j.scs.2012.03.001

Sreejesh, S., Mohapatra, S., \& Anusree, M. R. (2014). Questionnaire Design. In Business Research Methods (pp. 143-159). Springer.

https://doi.org/10.1007/978-3-319-00539-3 5

Suvorov, D. M., Suvorova, L. A., Pestova, I. V., \& Baibakova, T. V. (2018). The Dynamic Index of Urban Environment Quality as a Tool for Sustainable Urban Development. IOP Conference Series: Earth and Environmental Science, 177, Article ID: 012007. https://doi.org/10.1088/1755-1315/177/1/012007

Tong, C., Ye, W. H., \& Hou, B. (2006). Developing an Environmental Indicator System for Sustainable Development in China: Two Case Studies of Selected Indicators. Environmental Management, 38, 688-702. https://doi.org/10.1007/s00267-004-0352-y

Van der Maesen, L. J. G. (2013). Development: New Theoretical and Methodological Challenges for Social Quality Indicators. The International Journal of Social Quality, 3, 82105. https://doi.org/10.3167/IJSQ.2013.030106

Wang, H., Zou, X., Lai, K., Luo, W., \& He, L. (2021). Does Quality of Life Act as a Protective Factor against Believing Health Rumors? Evidence from a National Cross-Sectional Survey in China. International Journal of Environmental Research Public Health, 18, 4669. https://doi.org/10.3390/ijerph18094669

Westfall, M. S., \& de Villa, V. A. (2001). Cities Data Book Urban Indicator for Managing Cities. Asian Development Bank.

WHO (2021). WHOQOL: Measuring Quality of Life. https://www.who.int/tools/whoqol 